Joanna Składowska

Uniwersytet Jagielloński

\title{
Sposoby obejścia konstytucyjnego zakazu reelekcji — kazus Nikaragui
}

DOI: $10.19195 / 1643-0328.24 .3$

Słowa kluczowe: ograniczenia w reelekcji, reelekcja nieograniczona, Sąd Najwyższy, Nikaragua, Daniel Ortega, system prezydencki

\section{Wprowadzenie}

Nikaraguańska konstytucja z 1987 r. w oryginalnym brzmieniu nie przewidywała ograniczeń $\mathrm{w}$ reelekcji prezydenckiej. Zakaz powtórnej reelekcji inkorporowała nowela z roku 1995. Powracający w 2006 r. na urząd prezydenta Daniel Ortega był bezpośrednio zainteresowany przywróceniem elastyczności reguł wyborczych, jednak brak odpowiedniej większości w parlamencie nie pozwolił Sandinistowskiemu Frontowi Wyzwolenia Narodowego ${ }^{1}$ na zmianę konstytucji.

Obostrzenia w zakresie reelekcji prezydenckiej są rozwiązaniem powszechnie występującym w konstytucjach współczesnych państw. Ma to zapobiec m.in. nadużyciom towarzyszącym zbyt długiej koncentracji władzy w rękach jednej osoby. W praktyce zakazy te bywają obchodzone, często przy zachowaniu pozorów legalności. Przykładowo, prezydent kończący kadencję wskazuje swojego następcę: zaufanego współpracownika czy członka rodziny ${ }^{2}$. Po wygranych wyborach, za jego pośrednictwem, nadal ma realny wpływ na sprawowanie władzy. Kazus nikaraguański jest odmienny, sięgnięto bowiem po rozwiązania alternatywne, angażując trzecią władzę. Zakaz powtórnej reelekcji prezydenckiej zniósł wyrok Sądu Najwyższego z października 2009 r. Wyłączył on stosowanie art. 147 konstytucji (który zakazywał reelekcji bezpośredniej, jak również ograniczał liczbę kadencji prezydenckich do maksymalnie dwóch), mimo że przez kolejne pięć lat

\footnotetext{
${ }^{1}$ Hiszp. Frente Sandinista de Liberación Nacional, dalej także FSLN.

2 Takie działania spowodowały, iż niektóre państwa Ameryki Łacińskiej wprowadziły także wyłączenia co do kandydatów na urząd prezydenta w stosunku do osób spokrewnionych i spowinowaconych z ustępującym prezydentem. Więcej na temat: M.D. Serrafero, El control de la sucesión: reelección y limitaciones de elección presidencial por parentesco en América Latina, „Revista de Estudios e Pesquisas sobre as Américas” 9 , 2015, nr 1, s. 81-103.
} 
przepis ten nie został formalnie uchylony. Uczyniła to dopiero nowela ustawy zasadniczej, która weszła w życie w lutym $2014 \mathrm{r}$.

Jak zauważa Mario D. Serrafero ${ }^{3}$, badania na temat reelekcji nie mogą być prowadzone w oderwaniu od przyjętego systemu instytucjonalnego. Powinny uwzględniać m.in. takie czynniki, jak: długość kadencji, zakres kompetencji i ich faktyczne wykonywanie, istnienie konstytucyjnego i politycznego systemu kontroli egzekutywy, a także zwyczaje czy tradycje polityczne partii i ich liderów. Możliwość ponownego wyboru prezydenta w systemie parlamentarnym (w którym prezydent zazwyczaj sprawuje jedynie funkcje honorowe) ma inne znaczenie i może nieść inne konsekwencje niż reelekcja szefa egzekutywy w systemie prezydenckim.

Celem artykułu jest przedstawienie analizy procesu zmian nikaraguańskiej konstytucji w latach 1995-2014, nakierowanego na obejście, a docelowo zniesienie, zakazu reelekcji. W szczególności autorka zwróci uwagę na swoistą judykalizację tego procesu. Dogłębnej analizie poddane zostaną orzeczenia Sądu Najwyższego z 2009 i 2010 r., a niniejsze rozważania zawężone do zagadnienia reelekcji głowy państwa w systemie prezydenckim. Analiza obostrzeń oraz sposobu ich obchodzenia przeprowadzona będzie na przykładach zaczerpniętych z państw Ameryki Łacińskiej. Reelekcja rozumiana będzie jako możliwość ponownego wyboru danej osoby na urząd, który osoba ta już sprawowała bezpośrednio przed wyborami albo w okresie wcześniejszym.

\section{Kontekst historyczny}

W Ameryce Łacińskiej dyskusja na temat reelekcji toczyła się już na początku XIX w. Po uzyskaniu niepodległości nowe republiki, określając konstytucyjne ramy ustrojowe, musiały zdecydować także o ewentualnej dopuszczalności wyboru głowy państwa na kolejną kadencję ${ }^{4}$. Zdania były podzielone, a stanowiska ewaluowały w czasie, nierzadko zmieniając się w zależności od przyjmowanej perspektywy. Przykładowo, Simón Bolivar, inaugurując pierwsze posiedzenie Kongresu Narodowego w Angosturze, przekonywał, że nie ma „nic bardziej niebezpiecznego, niż pozwolić jednemu człowiekowi dzierżyć władzę przez długi czas. Naród przyzwyczaja się być mu posłusznym, a on przyzwy-

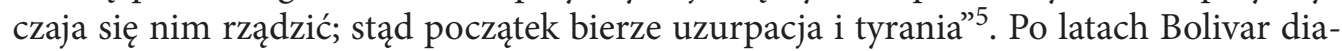

${ }^{3}$ M.D. Serrafero, La reelección presidencial indefinida en América Latina, „Revista de Instituciones, Ideas y Mercados", ESEADE 2011, nr 54, s. 225-259.

${ }^{4}$ Temat reelekcji prezydenckiej był publicznie dyskutowany także na etapie konstruowania rozwiązań ustrojowych Stanów Zjednoczonych. Zwolennikiem reelekcji był m.in. Alexander Hamilton, który w dyskursie z 1787 r. na łamach „The Federalist”, przytoczył liczne argumenty na rzecz reelekcji prezydenckiej. Argumentacja ta znalazła odzwierciedlenie w samej konstytucji. Formalnie nie przewidywała ona ograniczeń co do liczby kadencji prezydenckich. Faktycznie przyjęto jednak niepisaną regułę jednokrotnej reelekcji. Zasadę tą przełamał dopiero Franklin Delano Roosevelt, rozpoczynając swoją trzecią kadencję w 1940 roku, wygrywając także w kolejnych wyborach w 1944 r. Zmiany wprowadziła poprawka z 1951 roku, inkorporując wcześniejszą, niepisaną zasadę jednokrotnej reelekcji. Więcej na temat: J. Carey, The reelention debate in Latin America, „Latin American Politics \& Society” 2009, s. 80; M.D. Serrafero, La reelección..., s. 231-235.

${ }^{5}$ Actas del Congreso de Angostura (febrero 15, 1819-julio 31, 1819) Instituto de Derecho Público, UCV, Caracas 1969, s. 225-234. 
metralnie zmienił zdanie, argumentując konieczność kontynuowania władzy, albowiem tylko w ten sposób będzie mógł zrealizować stawiane cele. Podobnie było w Meksyku, gdy w kampanii z 1871 r. Porfirio Díaz, mierząc się z Benito Juárezem, żądał ograniczenia reelekcji. Po objęciu urzędu o żądaniu tym zapomniał. Co znamienne, do upadku Díaza, po 34 latach sprawowania władzy, przyczyniło się to samo hasło no reelección!, konsekwentnie powtarzane przez Francisco Madero w kampanii z 1910 r., przejęte następnie przez rewolucję meksykańską ${ }^{6}$.

Temat dopuszczalności reelekcji powrócił w ostatniej dekadzie ubiegłego wieku, wpisując się w szerszą debatę o wadach i zaletach sytemu prezydenckiego $\mathrm{w}$ porównaniu z parlamentaryzmem ${ }^{7}$. Zwrócono uwagę na negatywne skutki zakazu reelekcji: kryzys przywództwa, problem z sukcesją czy pokusę rządzenia $z$ „tylnego fotela”. Krytyce poddano kluczowy argument limitowania liczby kadencji, tj. stworzenie bariery przed nadużyciami, które mogą towarzyszyć koncentracji władzy w rękach jednej osoby. Podkreślono, że zakaz reelekcji nie spełnił oczekiwań i nie uchronił przed wieloletnimi dyktaturami. Co więcej, często był przyczyną niestabilności rządów w regionie, odbierając popularnemu i zaradnemu prezydentowi legalną możliwość kontynuowania mandatu oraz szansę realizacji programu wyborczego, z którego powodu dana osoba został wybrana na prezydenta ${ }^{9}$. Wskazywano, że o ile w słabych demokracjach zakaz reelekcji może okazać się zasadny, o tyle brak argumentów za jego stosowaniem tam, gdzie istnieje instytucjonalna struktura, która pozwala unikać manipulacji prowokowanych przez egzekutywę ${ }^{10}$.

Analiza porównawcza prowadzi do wniosku, że w XX w. w badanym regionie dominowały rozwiązania wyłączające lub ograniczające ponowny wybór na urząd głowy państwa. Przez dłuższy czas jedynie Paragwaj dopuszczał reelekcję bezpośrednią ${ }^{11}$. Zmiany przyniosły lata dziewięćdziesiąte ubiegłego wieku, kiedy przez region przetoczyła się fala reelekcjonizmu ${ }^{12}$, a kolejne państwa dokonały zmian w swoich ustawach zasadniczych. W 1993 r. Alberto Fujimori przeforsował zniesienie zakazu reelekcji w Peru. W jego ślady rok później poszedł Carlos Menem, ówczesny prezydent Argentyny. Obaj w roku 1995 skorzystali ze zmian i zostali wybrani na drugą kadencję. W 1998 r. nowelizacja konstytucji uchwalona została w Brazylii, a rok później w Wenezueli, gdzie rządy objął charyzmatyczny Hugo Chávez. Nowe tysiąclecie utrzymało trend zmian.

\footnotetext{
${ }^{6}$ J. Carey, op. cit., s. 80.

7 Uczestnikami debaty byli m.in.: J. Linz, G. Sartori, M.D. Serrafero, J. Carey, G.L Negretto i inni.

${ }^{8} \mathrm{~J}$. Linz, The perils of presidentialism, „Journal of Democracy” 1, 1990, nr 1, s. 5.

9 Ibidem, s. 60-61; M. Amaparo Casar, Las bases político-institucionales del poder presidencial en México, „Política y Gobierno”3, 1996, nr 1, s. 65-66.

10 S. Mainwarning, M.S. Shugart, Juan Linz, presidentialism and democracy: a critical appraisal, „Comparative Politics" 29, 1997, nr 4, s. 452.

${ }^{11}$ I. Treminio Sánchez, Las reformas a la reelección presidencial en América Latina, „Estudios Sociológicos" 31, 2013, nr 91, s. 65-67.

12 J.C. Arenas Gomez, G.D. Valencia, Elecciones y reelecciones presidenciales en América Latina, „Perfil de Coyuntura Económica" 2009, nr 12, s. 79-82; M. Penfold, J. Corrales, G. Hernandez, Los invencibles: la reelección presidencial y los cambios constitucionales en América Latina, „Revista de Ciencia Política” 34,
} 2014, nr 3, s. 539. 
Ilość zmian konstytucji w zakresie reelekcji prezydenckiej pozwala na wyciągnięcie wniosku, że regulacja ta jest jedną z najbardziej niestabilnych w Ameryce Łacińskiej ${ }^{13}$. Od połowy lat dziewięćdziesiątych XX w. zauważalna jest jednak względnie stała tendencja do zwiększania elastyczności reelekcji ${ }^{14}$. Za G.L. Negretto należy wskazać, że w latach 1978-2008 w Ameryce Łacińskiej miało miejsce szesnaście reform konstytucyjnych $\mathrm{w}$ tej materii, $\mathrm{z}$ czego siedem wprowadzało obostrzenia ponownego wyboru na urząd prezydencki, dziewięć zaś uelastyczniało reguły ${ }^{15}$.

\section{Typologia reelekcji}

W państwach Ameryki Łacińskiej brakuje jednego, uniwersalnego modelu reelekcji prezydenckiej. Funkcjonuje co najmniej kilka rozwiązań. Dwa skrajne to z jednej strony całkowity zakaz reelekcji (pierwsza kadencja jest zarazem ostatnią), z drugiej zaś - reelekcja nieograniczona: dana osoba może sprawować urząd prezydencki bez limitu kadencji. Pomiędzy wariantami granicznymi, w ślad za M.D. Serrafero ${ }^{16}$, wyróżnić można cztery rozwiązania pośrednie: 1) reelekcję bezpośrednią otwartą, przy której po dwóch kadencjach były prezydent może startować w kolejnych wyborach, jednak po odczekaniu określonego czasu; 2) reelekcję bezpośrednią zamkniętą, kiedy to po dwóch następujących po sobie kadencjach były prezydent traci prawo do startowania w wyborach; 3) reelekcję niebezpośrednią otwartą, gdy ponowne kandydowanie po upływającej kadencji nie jest możliwe, jednak po odczekaniu określonego czasu były prezydent starać się może o urząd bez ograniczeń; 4) reelekcję niebezpośrednią zamkniętą, kiedy po upływie okresu kadencji były prezydent może starać się o urząd ponownie, lecz tylko określoną ilość razy.

Całkowity zakaz reelekcji przewidują ustawy zasadnicze Meksyku, Gwatemali, Hondurasu i Paragwaju. Zupełną swobodę co do liczby kadencji odnajdziemy w Wenezueli (zniesienie ograniczeń w reelekcji nastąpiło jeszcze za czasów Hugo Cháveza), a od lutego 2014 r. także w Nikaragui. Reelekcja bezpośrednia wykluczona jest m.in. w Chile, Peru, Salwadorze czy Kostaryce. Natomiast w Argentynie, Brazylii czy Kolumbii urząd prezydenta może być sprawowany przez dwie następujące po sobie kadencje, bez prawa do startowania w kolejnych wyborach.

${ }^{13}$ G.L. Negretto, Paradojas de la Reforma Constitucional en América Latina, „Journal of Democracy en Español" 1, 2009, s. 38-54.

14 I. Treminio Sánchez, Las reformas a la reelección presidencial del nuevo siglo en América Central. Tres intentos de reforma y un golpe de estado, „Política y Gobierno” 22, 2015, nr 1, s. 148.

15 Więcej na ten temat G.L. Negretto, Shifting constitutional design in Latin America. A two level explanation, „Texas Law Journal” 89, 2011, nr 7, s. 1785-1787.

${ }^{16}$ M.D. Serrafero, La reelección ..., s. 229-230. 


\section{Nikaragua — ramy konstytucyjne reelekcji}

Ramy ustrojowe państwa określa Konstytucja Polityczna Republiki Nikaragui z 1987 r. ${ }^{17}$ Jest ona dziesiątą ustawą zasadniczą tej niewielkiej środkowoamerykańskiej republiki, licząc od uzyskania przez nią niepodległości. Stanowiła ona próbę implementacji zasad rewolucji sandinistowskiej na poziomie konstytucyjnym ${ }^{18}$. Mimo iż tworzona była w czasie głębokich przemian ustrojowych, okazała się aktem na tyle uniwersalnym, że pozwoliła na pokojową transformację po zwycięstwie opozycji w wyborach z $1990 \mathrm{r}^{19}$ Bez większych zmian stworzyła instytucjonalne ramy do rozpoczęcia procesu demokratyzacji.

Najmniej stabilną klauzulą konstytucji z 1987 r. była właśnie klauzula reelekcji prezydenckiej, zawarta w art. 147. Na przestrzeni dwudziestu siedmiu lat zmieniła się trzykrotnie, a zmiany zatoczyły koło: od wolnej reelekcji, przez reelekcję niebezpośrednią ograniczoną, do ponownego zniesienia obostrzeń. Ich podstawę stanowiły dwie nowelizacje konstytucji, a w okresie przejściowym ${ }^{20}$ wyroki Izby Konstytucyjnej Sądu Najwyższego.

W oryginalnym brzmieniu nikaraguańska konstytucja nie wprowadzała ograniczeń w liczbie kadencji prezydenckich. Jej twórcy wskazywali, że formalny zakaz reelekcji nie uchronił Nikaragui przed przeszło czterdziestoletnią dyktaturą klanu Somozów ${ }^{21}$. Obostrzenia w tym zakresie inkorporowała nowela z roku 1995. Po pierwsze, wyłączono reelekcję bezpośrednią. Po drugie, o ponowny wybór nie mogła się starać osoba, która sprawowała urząd prezydenta już dwukrotnie. Od 2007 r. podejmowane były kolejne próby uelastycznienia reguł wyboru głowy państwa. Zwrot o 180 stopni przyniósł rok 2009, w którym to wyrok Sądu Najwyższego Nikaragui wyłączył stosowanie restrykcji przewidzianych w art. 147 konstytucji. Kropkę nad „i” postawiła nowela z 2014 r., która zniosła wszelkie ograniczenia w tej materii.

Warto wskazać, że rozwiązania nikaraguańskie zachowują pewną odrębność i nie korespondują z tendencją zauważalną w regionie. Jak już wskazano, do połowy lat dziewięćdziesiątych XX w. w państwach Ameryki Łacińskiej dominował całkowity zakaz reelekcji. W tym okresie konstytucja Nikaragui nie przewidywała żadnych ograniczeń. Wprowadziła je nowela z 1995 r., a więc roku, w którym fala reelekcjonizmu obejmowała kolejne państwa. Obecnie, choć obserwuje się dalsze uelastycznianie reguł wyboru głowy państwa w regionie, to obok Nikaragui tylko Wenezuela przewiduje reelekcję nieograniczoną.

${ }^{17}$ Konstytucja Polityczna Republiki Nikaragui (hiszp. Constitución Política de la República de Nicaragua) z dnia 19 listopada 1986 r. (Dz.U. La Gaceta 94 z 30 kwietnia 1987 r.).

18 A. Aguilar Altamirano et al., Novena reforma constitucional 2014. El cambio de las reglas del juego democrático en Nicaragua, Managua 2014, s. 12.

19 S. Martí i Puig, Nicaragua y el FSLN (1979-2009): ¿Qué queda de la Revolución?, Barcelona 2009, s. 1920. Więcej na ten temat: L.E. Anderson, L.C. Dodd, Learning Democracy. Citizen Engagement and electoral choice in Nicaragua, 1990-2001, Chicago 2005; A. Gruszczak, Ameryka Środkowa, Warszawa 2007, s. 452-460.

${ }^{20}$ Który autorka rozumie jako okres pomiędzy wprowadzeniem ograniczeń przez nowelę z $1995 \mathrm{r}$. a przywróceniem wolnej reelekcji przez nowelę z lutego $2014 \mathrm{r}$.

${ }^{21}$ E. Castro Rivera, S.J. Cuarezma Terían, A 21 años de la Constitución Política: vigencia y desafíos, Managua 2008, s. 209. 


\section{Tło zdarzeń}

Głównym zainteresowanym uelastycznieniem reguł reelekcji był José Daniel Ortega Saavedra. Jesienią 2006 r. wygrał on wybory prezydenckie i w styczniu 2007 r. rozpoczął drugą kadencję. Obejmując urząd, miał świadomość, że formalnie był to jego ostatni start w wyścigu o fotel prezydencki. Artykuł 147 konstytucji w ówczesnym brzmieniu wyłączał bowiem zarówno reelekcję bezpośrednią, jak też limitował liczbę kadencji do maksymalnie dwóch. Przywódca Sandinowskiego Frontu Wyzwolenia Narodowego nie zamierzał jednak rezygnować z ponownego ubiegania się o urząd. W konsekwencji już w 2007 r. podjęto próby nowelizacji konstytucji. W tym okresie jednak partia rządząca nie dysponowała $\mathrm{w}$ parlamencie większością pozwalającą na przeprowadzenie procesu zmian. Próba sił z opozycją nie przyniosła zamierzonego efektu. W zniesieniu zakazu reelekcji Partia Liberalno-Konstytucjonalna dostrzegała niebezpieczeństwo wykluczenia z gry politycznej, natomiast Liberalny Sojusz Nikaragui podkreślał, że będzie to poważne zagrożenie dla demokracji. Sandiniści musieli poszukać alternatywnego rozwiązania. Sam Ortega nie wykluczał skorzystania z przykładu płynącego z Rosji. W jednym z wywiadów stwierdził, że jeśli warunki pozwolą, stanie ponownie do walki o urząd prezydencki, jeśli zaś nie - starać się może o tekę premiera, by następnie ponownie próbować sił w wyścigu o fotel szefa egzekutywy ${ }^{22}$.

Ostatecznie zdecydowano się skorzystać z rozwiązania stwarzającego pozory legalności, a inspirowanego doświadczeniem sąsiedniej Kostaryki ${ }^{23}$. Wykorzystano w tym celu najwyższy organ władzy sądowniczej. Na skutek nieformalnego paktu politycznego jeszcze z $2000 \mathrm{r}$., tzw. el Pacto ${ }^{24}$, FSLN bowiem miał wpływ na obsadę personalną składu Sądu Najwyższego.

\section{Wyroki nikaraguańskiego Sądu Najwyższego}

15 października 2009 r. Daniel Ortega wraz z grupą 109 burmistrzów wywodzących się z FSLN złożył na ręce Najwyższej Rady Wyborczej (CSE) ${ }^{25}$ wniosek o zbadanie zgod-

22 Deklaracja ta została złożona w wywiadzie dla Davida Frosta, dziennikarza prowadzącego program „Frost over the World” (emitowany w arabskiej stacji Al Jazeera). Cytat za artykułem Cuatro caminos para que Ortega se reelija, „El Nuevo Diario”, 10 marca 2009 r., http://www.elnuevodiario.com.ni/politica/42288-cuatro-caminos-que-ortega-se-reelija/ (dostęp: 20 maja 2017).

23 Sąd Najwyższy Kostaryki w wyroku z 14 kwietnia 2003 r. dopuścił do ponownego kandydowania na urząd prezydenta Oscara Ariasa, mimo iż konstytucja przewidywała bezwzględny zakaz reelekcji. Więcej na ten temat: E. Martínez Barahona, A. Brenes Barahona, „Y volver, volver, volver...” Un análisis de los casos de intervención de las Cortes Supremas en la Reelección Presidencial en Centroamérica, „Anuario de Estudios Centroamericanos" 2002, nr 38, s. 109-136.

24 Tzw. el Pacto, nieformalne porozumienie pomiędzy dwoma partiami FSLN Daniela Ortegi a PLC Arnoldo Alemana, na którego mocy określono zasady współpracy i faktycznego kontrolowania przed te dwie partie podstawowych organów państwowych (w szczególności ich obsady), w tym także Sądu Najwyższego. Więcej na ten temat: S. Martí i Puig, Nicaragua 2008: Polarización y pactos, „Revista de Ciencia Política” 29, 2008, nr 2, s. 515-531.

${ }^{25}$ Organ władzy wyborczej, do kompetencji którego należy dbanie o prawidłowy przebieg wyborów. 
ności z prawem nowelizacji konstytucji z 1995 r. w zakresie, w którym wprowadziła ona zakaz powtórnej reelekcji. Dzień później CSE wniosek odrzuciła, wskazując, że nie jest organem kompetentnym do rozpoznania sprawy, a skarżącym przysługuje droga sądowa. Odrzucenie wniosku otworzyło Ortedze i pozostałym szefom lokalnej egzekutywy wachlarz możliwości prawnych. Decyzję organu władzy państwowej zdecydowano się zaskarżyć przy wykorzystaniu nadzwyczajnego środka prawnego - recurso de amparo. Postępowanie zostało wszczęte jeszcze tego samego dnia, w którym CSE odmówiła rozpoznania sprawy. W skardze złożonej do Wydziału Cywilnego Sądu Apelacyjnego w Managui skarżący wskazali m.in., że nowela z 1995 r. w zakresie, w którym limituje reelekcję, uderza $\mathrm{w}$ ich prawa podstawowe gwarantowane ustawą zasadniczą, $\mathrm{w}$ jej wyjściowym brzmieniu. W szczególności dyskryminuje ich $\mathrm{w}$ porównaniu $\mathrm{z}$ innymi kandydatami. Sąd Apelacyjny niezwłocznie przekazał skargę do rozpoznania Izbie Konstytucyjnej Sądu Najwyższego. 19 października 2009 r. Sąd Najwyższy wydał wyrok ${ }^{26}$, w którym uznał skargę za zasadną. W konsekwencji w stosunku do Daniela Ortegi i pozostałych skarżących wyłączono stosowanie odpowiednio art. 147 i 178 konstytucji.

W uzasadnieniu orzeczenia Sąd Najwyższy podzielił argumentację przedstawioną w skardze. Uznał, że przedmiotowa nowelizacja zawiera postanowienia dyskryminujące skarżących i faktycznie ogranicza ich bierne prawo wyborcze. W dalszym wywodzie prawnym wskazał nadto, że parlament, który przyjął nowelę (a który nazwano konstytuantą pochodną), nie był uprawniony do wprowadzenia tego typu zmian. Zdaniem sędziów konstytuanta pochodna mogła jedynie poszerzyć zakres praw i wolności obywatelskich zagwarantowanych w konstytucji uchwalonej przez konstytuantę pierwotną. Nie była uprawniona do ograniczenia lub wyłączenia takich praw. Czyniąc to, uderzyła w zasadę zwierzchnictwa suwerena (narodu). Naruszyła podstawowe prawa wyborcze, tj. prawo do dokonywania wyboru i bycia wybranym.

Orzeczenie Sądu z 19 października 2009 r. miało moc wiążącą inter partes, a więc wywoływało skutek jedynie w stosunku do skarżących. Niespełna rok później, tj. 30 września 2010 r. $^{27}$, pełny skład Sądu Najwyższego zatwierdził wcześniejsze rozstrzygnięcie i orzekł o wyłączeniu stosowania art. 147 i 178 konstytucji erga omnes. Co znamienne, przywołane orzeczenia nie zmieniły literalnego brzmienia ustawy zasadniczej; nową treść nadała im dopiero nowelizacja z lutego 2014 r.

\section{Ocena wyroków Sądu Najwyższego}

Na skutek wydanych wyroków reelekcja nieograniczona stała się faktem. Choć formalnie postanowienia art. 147 i 178 konstytucji nie zostały uchylone, a ich treść pozostała bez zmian przez kolejne 5 lat, Sąd Najwyższy wyłączył ich stosowanie. Legalność takiego rozwiązania budzi poważne wątpliwości, szczególnie gdy uwzględni się wiele nieprawidłowości, które miały miejsce w związku z wyrokowaniem.

\footnotetext{
${ }^{26}$ Wyrok Izby Konstytucyjnej Sądu Najwyższego Nikaragui nr 504 z 19 października 2009 r.

27 Wyrok pełnego składu Sądu Najwyższego Nikaragui nr 6 z 30 września 2010 r.
} 
W pierwszej kolejności należy podkreślić, że wyrok Sądu Najwyższego, który wpływa na kształt konstytucji, faktycznie modyfikując jej postanowienia, wykracza poza standardy demokratycznego państwa prawa i przełamuje trójpodział władzy. Judykatura wchodzi bowiem w kompetencje legislatywy. To rolą parlamentu jest ewentualne uchwalanie nowelizacji ustawy zasadniczej, rolą sądów zaś stanie na straży przestrzegania prawa.

Nadto trzeba pamiętać, że przy orzekaniu sędziowie są niezależni i niezawiśli, podlegają jednak ustawom, a sędziowie sądów konstytucyjnych — ustawie zasadniczej. Oznacza to, że w wypadku kolizji dwóch norm są władni derogować postanowienia aktów niższego rzędu, jako sprzecznych $\mathrm{z}$ normami aktu prawnego umiejscowionego wyżej w hierarchii krajowych źródeł prawa (np. wyeliminować przepis ustawy jako niezgodny $\mathrm{z}$ ustawą zasadniczą). W kazusie nikaraguańskim natomiast w pierwszej kolejności sędziowie Sądu Najwyższego stwierdzili kolizję dwóch norm o tej samej randze: prawa do wybierania i bycia wybieranym oraz zakazu powtórnej reelekcji, a następnie wyeliminowali jedną z nich, orzekając o wyłączeniu jej stosowania. Innymi słowy, uznali za „niekonstytucyjne” samo postanowienie konstytucji. Stanowisko wyrażone w wyroku było w istocie arbitralną decyzją sędziów, którzy go wydali.

Zastrzeżenia budzi także sama możliwość użycia przez skarżących instrumentu prawnego, który finalnie doprowadził do wyłączenia zakazu reelekcji, tj. recurso de amparo. Jest to szczególny rodzaj środka zaskarżenia, który przysługuje jednostce w sytuacji, gdy w innym postępowaniu dochodzi do naruszenia jej praw podstawowych zagwarantowanych w konstytucji (art. 45). Sąd, uwzględniając skargę, może orzec także o niezgodności z konstytucją danego przepisu prawa ${ }^{28}$. Wyrok taki będzie miał jednak moc wiążącą tylko $\mathrm{w}$ danej sprawie. Warunkiem skorzystania $\mathrm{z}$ recurso de amparo jest jednak toczące się w stosunku do skarżącego inne postępowanie, co do którego zgłasza on zarzut naruszenia praw podstawowych. Natomiast w wypadku skargi Ortegi i 109 alcaldes nie toczyło się żadne postępowanie w stosunku do skarżących (organ władzy wyborczej nie wszczął postępowania w sprawie, a odrzucił wniosek, stwierdzając brak kompetencji do jego rozpoznania). Podobnie sama decyzja CSE o odrzuceniu wniosku nie naruszała praw skarżących (w szczególności praw wyborczych). W konsekwencji Sąd Najwyższy winien był odrzucić skargę jako niedopuszczalną, odstępując od merytorycznego rozpoznania sprawy.

Konieczne jest też uwzględnienie pozycji Sądu Najwyższego w ramach struktury władz państwowych w Nikaragui. Na skutek el Pacto, będącego z kolei reakcją na zmiany ustrojowe wprowadzone nowelizacją konstytucji z 1995 r., Sąd Najwyższy uległ silnemu upolitycznieniu. Podważa to jego niezawisłość i niezależność, a więc dwie podstawowe gwarancje funkcjonowania władzy sądowniczej. Sędzia nie jest mianowany dożywotnio na zajmowane stanowisko, lecz wybierany na pięcioletnią kadencję. Wyboru na stanowisko sędziego dokonuje parlament większością kwalifikowaną. Może on być w każdej

28 Więcej na ten temat: O.A. García Palacios, El recurso de amparo en el ordenamiento nicaragüense, „Revista del Instituto de Ciencias Jurídicas de Puebla” 2011, nr 27, s. 201-215. 
chwili odwołany i to zwykłą większością głosów. Powoduje to silne upolitycznienie sędziów, którzy w zasadzie nie kryją swoich politycznych preferencji ${ }^{29}$.

Co więcej, sprawa z wniosku Ortegi i 109 alcaldes rozpoznana została w składzie sześciu sędziów Izby Konstytucyjnej Sądu Najwyższego, jednak byli to wyłącznie sędziowie wybrani głosami FSLN. Takie wskazanie składu orzekającego stało w sprzeczności z przyjętą procedurą. Ważna jest bowiem zarówno liczba sędziów, jak i odpowiednia kompozycja. Daną sprawę winni rozpoznawać sędziowie wskazani przez przewodniczącego spośród sędziów zarówno „liberalnych”, jak i „sandinistowskich”. W późniejszych wywiadach przewodniczący Sądu Najwyższego tłumaczył, że do takiego wyboru zmusiła go sytuacja, albowiem w momencie delegowania sprawy dysponował tylko sędziami z jednej grupy. Sędziowie „liberalni” nie stawili się w Sądzie ${ }^{30}$. W konsekwencji recurso de amparo rozstrzygnęło sześciu sędziów z ramienia FSLN, a więc tej samej partii, z której wywodzili się skarżący.

Tego typu uchybienia formalne dotyczą także obsadzenia składu orzekającego przy drugim z orzeczeń. Wyrok z 30 października 2010 r. wydany został przez pełny skład Sądu Najwyższego. Po raz kolejny jednak byli to wyłącznie sędziowie związani z FSLN, mimo iż, co do zasady, w najwyższym organie władzy sądowniczej Nikaragui równoważyły się siły sandinistów i liberałów. Nieprawidłowości dotyczyły aż dziewięciu sędziów biorących udział w orzekaniu. Dwóm z nich została przedłużona kadencja na mocy dekretu prezydenckiego $\mathrm{nr} 3-2010 \mathrm{z} 9$ stycznia $2010 \mathrm{r}^{31}$ Siedmiu pozostałych zostało wybranych jako uzupełnienie składu w związku z nieobecnością sędziów „liberalnych”32.

Zastrzeżenia budzi także tempo rozpoznania sprawy. Od złożenia wniosku w CSE do wydania wyroku przez Sąd Najwyższy minęły cztery dni. Jeśli uwzględni się fakt, że dwa $\mathrm{z}$ nich były dniami wolnymi od pracy, to prędkość postępowania była iście zawrotna. W tak krótkim czasie nie jest możliwy sam obieg dokumentów pomiędzy trzema instytucjami, a co dopiero wydanie orzeczeń, przygotowanie uzasadnień i środków zaskarżenia. Przykładowo, uzasadnienie decyzji CSE składało się z ponad dwudziestu stron, a przygotowane zostało w niespełna dobę od wpłynięcia wniosku. Rozstrzygnięcie ogłoszone zostało w piątek 16 października 2009 r. o godzinie 11:45, a jeszcze tego samego dnia, niespełna pięć godzin później, inny organ, Sąd Apelacyjny w Managui, wydał postanowienie o wszczęciu postępowania wywołanego recurso de amparo. Po kolejnych trzech dniach wyznaczono skład orzekający Sądu Najwyższego, który w tym samym

${ }^{29}$ Przykładowo Sędzia Rafael Solís Cerda w publicznym wywiadzie przyznał: „byłem sandinistą, zanim zostałem wybrany do orzekania w Sądzie Najwyższym [...] tworzymy polityczną rzeczywistość partyjną [... ] tak, oczywiście utrzymujemy nasze sympatie [...]” - cyt. za: E. Martínez Barahona, Las Cortes Supremos como mecanismo de distribución de poder: el caso de la reelección presidencial en Costa Rica y Nicaragua, „Revista de Ciencia Política” 30, 2010, nr 3, s. 745.

${ }^{30}$ E. Martínez Barahona, Cortes Supremas y candidaturas presidenciales en Centroamérica, „Revista de Estudios Políticos (Nueva Época)" 2012, nr 158, s. 181-182.

${ }^{31}$ Dekret nr 3-2010 wydany 9 stycznia 2010 r., opublikowany w La Gaceta nr 6 z 11 stycznia 2010 r.

32 Więcej na ten temat: E. Martínez Barahona, Constitutional Court and Constitutional Change: analyzing the cases of presidential re-election in Latin America, [w:] D. Nolte, A. Schilling-Vacaflor, New Constitutionalism in Latin America. Promises and Practices, Ashgate, Surrey 2012, s. 295-296; E. Martínez Barahona, Cortes Supremas..., s. 183-184. 
dniu wydał komentowany wyrok. Stawia to pod znakiem zapytania rzetelność całego postępowania oraz skłania do wniosku, że poszczególne kroki prawne i rozstrzygnięcia były już wcześniej przygotowane, a Sąd Najwyższy wykonał to, co zaplanował Daniel Ortega: dokonał faktycznej zmiany konstytucji, na co wcześniej sandinistom nie starczyło politycznych sił w parlamencie.

Wątpliwa jest wreszcie sama motywacja przedsięwziętych kroków prawnych. Nie można zapominać, że Daniel Ortega (a także pozostali skarżący) byli osobiście zainteresowani wynikiem postępowania. Celem działania było uzyskanie możliwości ponownego startu w wyborach. Beneficjentem skutków prawnych zapadłych wyroków byli funkcjonariusze publiczni: urzędujący prezydent oraz lokalni szefowie egzekutywy. Czynności podjęte w celu zniesienia zakazu powtórnej reelekcji uderzyły w prawa człowieka wytyczone międzynarodowymi standardami, w szczególności w prawo dostępu do służby publicznej na równych zasadach ${ }^{33}$, a więc prawo gwarantowane art. 23.1 litera c) Amerykańskiej Konwencji Praw Człowieka, jak również art. 25 lit c) Międzynarodowego Paktu Praw Obywatelskich i Politycznych.

\section{Podsumowanie}

Komentowane wyroki Sądu Najwyższego Nikaragui budzą poważne wątpliwości co do ich zgodności z prawem.

Po pierwsze, zastosowany mechanizm, w którym przy orzekaniu w konkretnej sprawie dokonywana jest abstrakcyjna wykładnia przepisów konstytucji, mająca wiązać erga omnes, stoi w sprzeczności z podstawowymi zasadami demokratycznego państwa prawa. Uderza w zasadę trójpodziału władzy (w systemie prezydenckim rozumianej zazwyczaj w sposób bardzo rygorystyczny). W badanym wypadku organ władzy sądowniczej dokonuje faktycznej zmiany konstytucji, ingerując tym samym w podstawowe uprawnienie władzy ustawodawczej. Co znamienne, Sąd Najwyższy Nikaragui czyni to bez żadnej podstawy prawnej, nie mając $\mathrm{w}$ tym zakresie ani wyraźnych, ani domniemanych kompetencji. Komentowane wyroki nie mieszczą się w kategorii wykładni przepisów prawa zastrzeżonej dla Sądu Najwyższego. Wykładnia dotyczyć może bowiem przepisów ustaw i aktów niższego rzędu, a dokonywana jest w odniesieniu do norm zapisanych w konstytucji, ewentualnie w ratyfikowanych umowach i traktatach międzynarodowych. Intencją cytowanych wyroków natomiast jest nadanie konstytucji nowego brzmienia. Zmiana prawa należy do kompetencji władzy ustawodawczej. Sądownictwo dokonywać może jego wykładni. Uprawnienia te nie są tożsame.

Po drugie, Sąd Najwyższy, wydając komentowane wyroki, stawia się ponad prawem. Przyjmuje za pewnik, że jest uprawniony do odkodowania woli narodu. W konsekwencji arbitralnie przesądza, że wyrazem woli suwerena było wyjściowe brzmienie art. 147 konstytucji, a więc brak ograniczeń w reelekcji. Zakłada niezmienność stanowiska su-

${ }^{33}$ M. Rodríguez Saldaña, Reformas constitucionales y reelección presidencial en Iberoamérica, [w:] Contribuciones al Derecho Constitucional, red. J.M. Serna de la Garza, México 2015, s. 613. 
werena w czasie, co dyskwalifikuje zakaz powtórnej reelekcji, wprowadzony nowelizacją z $1995 \mathrm{r}$. Wprowadza niczym nieuzasadnione rozróżnienie, zgodnie z którym ta sama aktywność Zgromadzenia Narodowego, mimo zachowania procedur przewidzianych prawem, raz jest wyrazem woli suwerena (przy uchwalaniu konstytucji), a raz jest pozbawiona takiego przymiotu (przy jej zmianie). Tym samym Sąd Najwyższy stawia się ponad prawem i niczym alfa i omega orzeka o „niekonstytucyjności” postanowienia samej konstytucji.

Po trzecie, nie można zapominać o tym, w jaki sposób dokonywana jest obsada stanowisk w Sądzie Najwyższym. W realiach nikaraguańskich oznacza to karykaturalną wręcz zależność polityczną najwyższego organu władzy sądowniczej od głównych ugrupowań w parlamencie. Podważa to autorytet trzeciej władzy. Sąd Najwyższy staje się wykonawcą woli polityków, którym nie starczyło sił w procesie legislacyjnym. Na mocy dwóch wyroków sądowych zniesiony zostaje zakaz powtórnej reelekcji. Okazuje się, że w realiach nikaraguańskich sześciu sędziów Sądu Najwyższego ma większą moc sprawczą niż kilkukrotnie większa grupa deputowanych w parlamencie (acz nadal niewystarczającą, by dokonać nowelizacji konstytucji). Wydanym w pośpiechu wyrokiem ominięto skomplikowaną i długotrwałą proceduję legislacyjną.

\section{Bibliografia}

Actas del Congreso de Angostura (febreto 15, 1819-julio 31, 1819) Instituto de Derecho Público, UCV, Caracas 1969, s. 225-234.

Aguilar Altamirano A., Esperanza Silva A., Sandino A., Zepeda Rivera M., Novena reforma constitucional 2014. El cambio de las reglas del juego democrático en Nicaragua, Managua 2014.

Amaparo Casar M., Las bases político-instutucionales del poder presidencial en México, „Política y Gobierno” 3, 1996, nr 1 .

Amerykańska Konwencja Praw Człowieka.

Anderson L.E., Dodd L.C., Learning Democracy. Citizen engagement and electoral choice in Nicaragua, 19902001, Chicago 2005.

Arenas Gomez J.C., Valencia G.D., Elecciones y reelecciones presidenciales en América Latina, 2009, „Perfil de Coyuntura Económica" $2009 \mathrm{nr} 12$.

Carey J., The reelention debate in Latin America, „Latin American Politics \& Society” 2009.

Castro Rivera E., Cuarezma Terían S.J., A 21 años de la Constitución Política: vigencia y desafíos, Managua 2008.

Dekret nr 3-2010 wydany 9 stycznia 2010 r. (La Gaceta nr 6, 11 stycznia 2010 r.).

García Palacios O.A., El recurso de amparo en el ordenamiento nicaragüense, „Revista del Instituto de Ciencias Jurídicas de Puebla" 2011, nr 27.

Gruszczak A., Ameryka Środkowa, Warszawa 2007.

Konstytucja Polityczna Republiki Nikaragui z 19 listopada 1986 r. (La Gaceta nr 94, 30 kwietnia 1987 r.).

Linz J., The perils of presidentialism, „Journal of Democracy” 1, 1990, nr 1.

Mainwarning S., Shugart M.S., Juan Linz, presidentialism and dedemocracy: a critical appraisal, „Comparative Politisc" 29, 1997, nr 4.

Martínez Barahona E., Constitutional Court and Constitutional Change: analyzing the cases of presidential reelection in Latin America, [w:] D. Nolte, A. Schilling-Vacaflor, New Constitutionalism in Latin America. Promises and Practices, Ashgate, Surrey 2012. 
Martínez Barahona E., Cortes Supremas y candidaturas presidenciales en Centroamérica, „Revista de Estudios Políticos (nueva época)" 2012, nr 158.

Martínez Barahona E., Las Cortes Supremos como mecanismo de distribución de poder: el caso de la reelección presidencial en Costa Rica y Nicaragua, „Revista de Ciencia Política” 30, 2010, nr 3.

Martínez Barahona E., Brenes Barahona A., „Y volver, volver, volver...” Una análisis de los casos de intervención de las Cortes Supremas en la Reelección Presidencial en Centroamérica, „Anuario de Estudios Centroamericanos" 2010, $\mathrm{nr} 38$.

Martí i Puig S., Nicaragua y el FSLN (1979-2009): ¿Qué queda de la Revolución?, Barcelona 2009.

Martí i Puig S., Nicaragua 2008: Polarización y pactos, „Revista de Ciencia Política” 29, 2008, nr 2.

Międzynarodowy Pakt Praw Obywatelskich i Politycznych.

Nowelizacja konstytucji z 1 lutego 1995 r. - ustawa nr 192 (La Gaceta nr 124, 4 lipca 1995 r.).

Nowelizacja konstytucji z 3 lipca 1995 r. - ustawa nr 199 (La Gaceta nr 125, 5 lipca 1995 r.).

Negretto G.L., Paradojas de la Reforma Constitucional en América Latina, „Journal of Democracy en Español" $1,2009$.

Negretto G.L., Shifting constitutional design in Latin America. A two level explanation, „Texas Law Journal” 89, 2011, nr 7.

Penfold M., Corrales J., Hernandez G., Los invencibles: la reelección presidencial y los cambios constitucionales en América Latina, „Revista de Ciencia Política” 34, 2014, nr 3.

Rodríguez Saldaña M., Reformas constitucionales y reelección presidencial en Iberoamérica, [w:] Contribuciones al Derecho Constitucional, red. J.M. Serna de la Garza, México 2015.

Serrafero M.D., La reelección presidencial indefinida en América Latina, „Revista de Instituciones, Ideas y Mercados", ESEADE 2011, nr 54.

Serrfero M.D., El control de la sucesión: reelección y limitaciones de elección presidencial por parentesco en América Latina, „Revista de Estudios e Pesquisas sobre as Américas” 9, 2015, nr 1.

Treminio Sánchez I., Las reformas a la reelección presidencial en América Latina, „Estudios Sociologicos” 31, 2013, nr 91, El Colegio de México, A.C.

Treminio Sánchez I., Las reformas a la reelección presidencial del nuevo siglo en América Central. Tres intentos de reforma y un golpe de estado, „Política y Gobierno” 22, 2015, nr 1.

Wise M.B., Judical Reviwe and its politicization in Central America: Guatemala, Costa Rica and Constitutional Limits on Presidential Candidates, „Santa Clara Journal of International Law” 7, 2010, nr 2.

Wyrok Izby Konstytucyjnej Sądu Najwyższego Nikaragui nr 504 z 19 października 2009 r.

Wyrok pełnego składu Sądu Najwyższego Nikaragui nr 6 z 30 września 2010 r.

\section{The exclusion of the constitutional ban against reelection - example of Nicaragua}

Keywords: limits of re-election, unlimited re-election, Supreme Court, Nicaragua, Daniel Ortega, presidencialism

Summary

The Nicaraguan Constitution of 1987 in its original version guaranteed the free presidential re-election. The limits clause has been introduced by the amendment of 1995. Daniel Ortega who returned as the president in 2006 was directly interested in removing the restriction. The Sandinista National Liberation Front has no required majority in Parliament to carry out the amendment procedure. They seek the alternative solution, such as judicial instrument. The Nicaraguan Supreme Court sentence emitted on 19th of October 2009, declared the inapplicability of 147 of Constitution. The way to unlimited re-election has been opened. 
The purpose of the article is to analyse the process of changes of Nicaraguan Constitution between 1995 and 2014, regarding the re-election clause. The judicalization of this process shall be emphasized. In particular, the author will present legal analyse of both sentences of Nicaraguan Supreme Court (i.e. emitted in October 2009 and September 2010). It will be assessing in the context of the president-election's regulation in Latin America presidentialism. 